\title{
A MODEL OF ACADEMIC GUIDANCE IN UNIVERSITY
}

\author{
By: \\ Eti Nurhayati \\ IAIN Syekh Nurjati Cirebon \\ (e-mail: etinoorhayatie09@gmail.com. HP. 081564610679)
}

\begin{abstract}
Abstrak: Model Bimbingan Belajar di Perguruan Tinggi. Tulisan ini merupakan hasil penelitian membahas pentingnya bimbingan belajar karena beberapa alasan yang bersifat internal dan eksternal untuk menunjang kesuksesan belajar dan menyongsong masa depan bagi mahasiswa. Penelitian ini bertujuan menghasilkan model bimbingan belajar untuk meningkatkan keterampilan berpikir dan kemandirian dalam belajar dengan menggunakan pendekatan Research and Development (R\&D) melalui empat tahapan: studi pendahuluan, merancang draf model, memvalidasi draf model, dan menguji model di lapangan. Metode penelitian menggunakan kuasi eksperimen dengan desain The pretest and posttest non-equivalent control group design. Hasil penelitian menyimpulkan, model bimbingan yang telah diuji di lapangan terbukti secara meyakinkan dapat meningkatkan keterampilan berpikir kritis dan kreatif serta kemandirian, baik aspek pengetahuan, keterampilan, maupun sikap dalam belajar.
\end{abstract}

Kata kunci: Bimbingan akademik, keterampilan berpikir, kemandirian belajar.

\section{INTRODUCTION}

Each individual carries his own natural tendency to live within his innate attributes independently. In this sense, developing independence including independent learning, means developing human natural tendency as his basic need of life. When childhood and have not been able to act autonomously, a child has difficulty to be independent, because his feeling and infantile bond that has long attached to him, so it is not easy to break away from infantilism, except with the exercises, habituation, and guidance. The children should be assisted and shaped by the environment around where they were to be independent. The need for self gradually formed and reached its peak in the post-adolescence.

Similarly, thinking skill is one of the essential learning skills that each student should develop for it is a tool for learning. Thinking skill that is seriously needed to be developed includes critical and creative thinking skills. Therefore, critical thinking skills and creative thinking as type of skills should be developed on the student to achieve learning goals.

The foregoing statements reveal that it is so important to develop thinking skills and independent learning for student in learning. So, it is need a high time to provide academic guidance service at university level. More specifically, it is critical to maximize 
the role and function of academic guidance service, including academic advisor, wellprogrammed service, well-planned materials and procedures, techniques for counseling that match students' age, and evaluation to get feed back from the program.

This model of academic guidance has been tested in the field, and could be used as an alternative model for lecturers as supervisors (PA) to inspire, stimulate, and motivate them to increase a quality of guidance for students in accordance with the problems faced by students, based on their characters, and the context of the times as development era of science and technology that demands mastery of more advanced skills and independent learning more higher, not only skills and independent learning in conventional ways were out of date to solve today's and future's problems.

\section{RESEARCH BACKGROUND}

The essence of learning at university to develop patterns of thinking in the cognitive structure of students, not just pragmatically to obtain the matter as much as possible in subject and get a high score (Wahidin, 2004: 4). Students' thinking by Piaget has entered the stage of "formal operational", in which they are able to think abstractly, hypothesis, critical, reflective, and constructive (Miller, 1993: 60-62). With such thinking, students are expected to have competence in thinking as one of the necessary learning skills, which in they are able to learn individually what science is needed by themselves. By thinking skills and independent learning, students are expected to integrate their knowledges and experiences with attitudes and values in their environment, in order that to be able to solve learning problems and life issues.

Moreover, the thinking process is different from the learning process. Learning process is a process of receiving knowledge from outside and kept in mind. Otherwise, in the thinking process, knowledge as the basic capital to do thinking process.

According to Sidjabat (2008: 1-3), in now days the teaching in classes, even if at university level, is just to transfer knowledge to students as much as possible instead of transferring learning skills. According to Sidjabat, this learning strategy is less benefit, the students will grow up to be less creative, poor ideas, and learning to be "dry" is not meaningful, because they are "forced" more matters or informations provided by teachers, so that might eliminate their roles, creativities, and responsibilities. The impact that, they couldn't able to construct their own knowledge and experiences, couldn't develop 
themselves, and couldn't able usually to compare between theory and reality in life (http://www.tiranus.net/?p20).

Furthermore Sidjabat (2008: 5-7), that the ideal teaching at university must be giving more opportunity for students to have adequate thinking skills, not only to remember the facts given by lecturers, but should be able to view the facts behind the phenomenon. So, the learning process is not only aimed at considering the facts, but more than that or learning beyond the facts. Developing the learning process with emphasizing students'opportunity to have the thinking skills will be more empowering and meaningful. By giving them facilities to think and act in their own way, so that they would contribute significantly through learning. It's same with Husen's opinion "Students must been taught to explore their own knowledge and to apply it to what is already known. So, university just provides thinking skills for themselves" (Husen, 1995: 85).

Similarly, thinking skill is one of the essential learning skills that each student should develop it as learning tools used to solve learning problems and also their life problems in general (Dahlan, dkk., 1996:23; Wahidin, 2004:6; Novak \& Gowin, 1999: 59).

The experts recommend two types of thinking strategies, both are convergent and divergent to develop thinking skills in a balanced way. Convergent strategy is proven to improve critical thinking skills, logical, systematic, and planned, while divergent strategy is proven to generate creative thinking, and imaginative. Thinking as a mental process is done by someone who aims to solve problems faced by his interpretation of the phenomenon (http://en.wikipedia.org/wiki/convergent and divergent production).

The university is the highest level in the education system. If university were less successful forging of thinking skills, including critical thinking and creative thinking to its students, the university lost the moment to produce a brilliant generation of intellectually and emotionally. Lose moment this means, losing some of the functions of universities. Therefore, universities in addition to conduct learning in classes, must also provide academic guidance services are not just there, but its function was perceived by students to support learning success.

Therefore the mission of learning in university is to develop responsibility for learning and reducing dependency on others, given the problems facing the present and future can not be solved only by means of conventional thinking, infantile, and dependent, 
but requires critical thinking, creative thinking skills, and independent in learning, so that the resulting solutions more constructive, progressive, contextual, and consequential.

The urgency of academic guidance at university based on analysis of internal and external students'factors. As known, the age of students Stratum 1 (S1) is generally around 18 - 24 years, which are in the transition from adolescence to adulthood (Hurlock, 1980:207).

Internal factors, there are at least four ideal reasons. First, each individual has internal potential to develop his thinking power. According to Piaget, the age of students had reached the stage of cognitive "formal operational", which was able to think of abstract, hypothetical, and critical (Miller, 1993: 60). Development of formal operational, students thinking might be independently than ever before, which is necessary to prepare themselves into job field and to develop their future career in accordance with their potentials, talents, and interests.

Secondly, an internal motivation achieves independence at that time. Students' age according to Erikson's psychosocial theory, they have reached the stage of identity formation (Lerner \& Hullsch,1983: 319) which in were fighting for independence as a manifestation of their maturity. As result, they would be independent and released from dependence of parents and other adults (Hurlock, 1980:209). In addition, they began to acquire identity of gender role, internalized moral, choosing a career, trying adult roles, finding identity, and beginning to work (Newman \& Newman, 1987: 119-125). According to Gormly \& Brodzinsky (1993: 396) they said: "Youth age is a period of development in which an individual is legally an adult but has not yet undertaken work and adult roles ". This suggests a characteristic of maturity is independent which demonstrated by the ability of responsible and making decisions, such as Fasick (in Rice, 1996: 336) describes: "One goal of every adolescent is to be accepted as an autonomous adult". Consequently, they emotionally do not want to be dictated, controlled, advised, arranged, called a child and blamed by others, despite the fact they are often not independent in the act.

Third, an internal needs on individuals to actualize himself independently as a manifestation of his maturity (Knowles, 1970: 120-127) so that the independence of the cognitive aspects, attitudes, or actions, also in learning, are as duties of developmental student age. In the beginning was not easy for students to grow toward independence, because the attempt to break the bond that has developed infantile and enjoyed with great 
sense of comfort during childhood, often leads to reactions that are difficult to understand by themselves (Rice, 1996: 512). They often can not release childhood emotional bonds with parents and teachers, even if logically and objectively. Consequently, they sometimes argue, and criticize the attitudes of adults. Although, these are difficult to be understood by themselves, that is why parents and teachers need to to develop their independence wisely, because of achieving their independence be come a common task for those who have stepped up (Steinberg, 1993: 454-470).

Fourth, an internal potential that be able to study independently. According to Merriam \& Caffarella (1999: 314-320): Age of students had seen enough and capable of designing programs and learning activities in accordance with the interests and ideals and how they learn differently from the way children learn. The experts also argue, the age of students should be able to initiate to diagnose learning needs, what will be learned and how to learn, can choose an appropriate learning strategies for themselves, can make important decisions in accordance with learning needs, can set their own learning activities on its own initiative in a responsible manner, without always depending on others, can students learn according to his needs, and can evaluate the results of their own learning (Gredler in Munandar, 1993:98-111; Knowles, 1970: 127; Kozma, Belle, William, 1978: 111-116; Aristo, 2008: 1-10 from http//:www.adiprama.com/dears.html; Wedmeyer, 1973:1-8 from http//:www. heghlaid school.org. uk/itt/ whole learner independent.html).

Considering from external factors, there are three reasons. First, an external demand of learning system such as Semester Credit System (SKS) which applied in universities. The main characteristics learning with SKS, that students' independent learning is preferred, both in the implementation of learning process and in management of themselves. Students are required to learn themselves, to seek, find, and utilize learning resources, to review and understand lecture subject, otherwise they can not rely entirely on teachers or others in the learning. They also determine what is beneficial to themselves, especially with tight restrictions on time of study, required them making good planning and mastering independent learning skills.

Secondly, external conditions such as a current progress of sciences and technology which is required by mastery of critical and creative thinking skills in learning. As result, the provision resources and learning methods have been implied in universities. Than, it is being needed to master various skills, such as to acquire, manage, and use information 
optimally and effectively as possible for the progress of life. Because of current information continuously, especially internet technology in which can be accessed the information from various corners of the world efficiently. In fact, developing countries can rule the world by mastering information. So, students must search various informations by mastering any skills to access and select an useful information as well as possible. Usually, information received isn't structured, so need to master some skills to organize it to be easily understood and can be useful for the progress of life.

Third, the external demands as a servant of God to use potential of thinking continuously. Age of students in terms of Islam, has included mukallaf, which is already to do and understand religion obligations. Many verses of the Qur'an that give a moral message in order to develop the power to think, either in the form of rhetorical sentences, as if you all do not think? · أفلاتعقلون • أفلاتتفكرون • أفلاتتدبرون · أفلاتعلمون, or the word of God in the form of news sentences and statements, among others listed in QS. Ali Imran [3]: 190191 dan QS. Al-A'raf [17]: 179.

Listening to those paragraphs, the term jahannam or "hell" essentially means that God has provided a very miserable place for people who have been given the potential of thinking but didn't use potentially, or can be interpreted as figuratively (majazi), would be lost and miserable for those who do not use the power of thinking, both in this world and hereafter. Demands to think this is what distinguishes man from animals, so God confirms in those words, the people who do not use the heart, eyes and ears as a tool of thinking, like animals, even more heinous.

Reasons above that support the importance of student's learning skills and independent learning, according Semiawan (1992: 6) because: (1) development of science and technology is increasingly rapid progress that might not educators teach all concepts and facts to students, but equip them with various learning skills, (2) discovery science and technology is absolutely not true $100 \%$, it's relative, so that by provision of learning skills they had, students' could learn individually to discover and prove the truth from (http//:mijischool multiply.com/journal/item/36).

According to Wahidin (2004: 103), scores of thinking skill of students who obtain training is higher than students who didn't yet obtain it. The experts also agree that thinking skills can be improved through training and learning (deBono, 1998: 23-45; Nor \& Dahlan, 2000b: 2; Liliasari, 1996: 15). Therefore, critical and creative thinking skills 
into the curriculum at the Kebangsaan University in Malaysia as a compulsory subject must be studied by all students (Wahidin, 2004: 104; Nor \& Dahlan, 2000a: 98-112). A Good criterion in thinking process according to Nickerson et al. (1985: 417-424) involves four components: (1) Thinking requires knowledge, (2) Thinking involves mental process that requires skill, (3) Thinking is active, (4) Thinking brings in attitudes. Rampingan et al. explained that: (1) Process of thinking can be learned, (2) Process of thinking is an active transaction between individual, and lectures can assist students in conceptualizing of mental processes, (3) Process of thinking developed in stages and requires a systematic strategy (Rampingan, et al., 1981: 34-38).

Thus was the independent learning which related to the environment that provides opportunities to develop aspects of independence, as a responsible freedom, sense of identity, and psychosocial health (Lipps \& Skoe, 1998: 213-240). Steinberg (1993: 293) asserts, "emotional autonomy develops under conditions that encourage both individuation and emotional closeness". According to Collins (in Montemayor, 1990: 101), "adolescents can become emotionally autonomous their parents without becoming detached form them".

Although thinking skills and independent learning are the potential and internal needs of each students as described above, but it is not automatic in learning without training, conditioning, and guiding. According to experts, most students haven't been able to be independent, still often rely on others in their learning (Gormly \& Brodzinsky, 1993: 396; Newman \& Newman, 1987: 130).

Based on some of opinions mentioned above, thinking skills and independent learning can be trained and improved gradually through a systematic strategy. Academic guidance services can be programmed systematically to help students to improve thinking skills and independent learning.

According to Piaget's paradigm of Constructivism that one of the important skills possessed by students is the skill to regulate and control the thinking process, including: (a) critical thinking skills of individuals using thinking strategies to analyze arguments and give an interpretation based on the perception that correct and rational, analytical assumptions, the bias of the arguments, and logical interpretation (b) creative thinking skills was the individual skills of using thinking processes to generate new ideas and constructive based on the concepts and principles of rationale and perception, and intuition of individuals (Preisseisen in Costa, 1985: 129-136). 
The urgency to develop independent learning by Semiawan (1992: 11-12) for: (a) reducing dependence on others, (b) grow the natural process of mental development, (c) develop responsibility for learning.

Based on the above Semiawan opinion clear that the mission of adult learning is to develop responsibility for learning and reduce dependency on others, as mentioned: "It is essential for schools to reduce students'dependency on schools and teachers for their learning and enhanced students' capability in set and meet their own learning goals" (http://www. sasked.gov.sk.ca/docs/policy/cels/e17.html).

Critical thinking is known as convergent thinking, and creative thinking known as divergent. Both these skills should be developed in a balanced way. Both skills are like two sides of a coin that can not be separated from one side to another, although they are different characteristics, but are used to complement each other, as mentioned below:

Convergent and divergent thinking skills are both important aspects of intelligence and critical thinking. Not only that, they are interrelated ... Both are used for solving problems, doing projects and achieving objectives ... convergent and divergent thinking skills are two sides to the same coin of critical thinking. One without the other does not make sense ... Some researchers have claimed that creative achievement actually involves both divergent and convergent thinking. Divergent thinking to generate new ideas, and convergent thinking to reality test them in order to determine if they will work (http://en.wikipedia.org/wiki/convergent and divergent production; http://faculty. washington.edu/ezent/imdt.html).

In perspective obove, it is important to develop a model that is more functional guidance services in accordance with student needs. A model of academic guidance that was developed as an alternative model for saturation refreshing supervisor from the guidance system which has lasted for this, as well as an ability to develop media in the field of coaching to the students as expected by some supervisors revealed through interviews, so the task a lecturer who has been in the supervisor SK's not just a formality.

Based on background above, the research hypothotical are: First, the model of academic guidance enhanced higher level of thinking skill of experimental group students than the control group ones. Second, the model of academic guidance enhanced higher level of independent learning of experimental group than the control group ones.

\section{RESEARCH METHOD}

Based on some of the reasons, the author has researched to obtain a model of guidance learning to improve thinking skills, especially critical thinking and creative 
thinking, and also independent learning of students at the State Islamic Institute (IAIN) Sheikh Nurjati Cirebon in 2010.

This research used Research and Development $(\mathrm{R} \& \mathrm{D})$ design. $\mathrm{R} \& \mathrm{D}$ is a process used to develop and validate educational product (Borg \& Gall, 1989: 5). R \& D design was employed to investigate the issues. It passed four stages: First, conducting preliminary study of overview academic guidance services. This study included a review of related academic guidance researchs, analysed academic guidance services, especially in IAIN Cirebon; Second, designing draft framework model includes: rationale, objectives, principles, assumptions to success, target, implementation, techniques, time, strategy, matters, and procedures of academic guidance; Third, validating draft model with data analysis. At this stage, research concucted a data analysis between pretest dan posttest implementation; Fourth, examining model to comprehend the effectivity of the model to be developed.

The author also has tested the model of academic guidance in the field by using quasi-experimental methods The pre and post-test nonequivalent Control Group design, its a design adopted from Campbell and Stanley (1966: 47-50).

While data collection techniques consist of questionaire distribution to the respondents to get the information about their levels of thinking skill and independent learning, interview for academic advisors to get the data on the available academic guidance services, and interview for institutional manager to get descriptions on policy and supprot for academic guidance services. The data, then analyzed using descriptive qualitative, descriptive statistics and comparison test method using statistical Analysis Covariance (ANCOVA) with SPSS 16.0 for windows.

\section{RESULTS AND DISCUSSIONS RESEARCH}

Students who were treated with model of guidance learning, their results of performance can be compared with students who are not treated as research result which analyzed by Ancova statistical. Ancova aimed to know the influence a model of academic guidance (independent variable) toward the critical and creative thinking skills and independent learning in the aspects of knowledge, attitudes, and skills (dependent variable) by controlling students'gender and their origin school. The results can be showed briefly as follows: 
1. The rank of thinking skills of students who follow academic guidance model is higher than students who didn't follow it. The influence of academic guidance model toward increasing the rank of learning skills is $33 \%$. The factor of origin school or gender partially didn't influence toward the improving of students'thinking skills, but the origin school and gender simultaneously influence toward the improving of students' thinking skills. Male students from public schools have a very high learning skills after being treated guidance learning, however the male students from religious schools have a very low learning skills. For the female gender from public or religious schools have almost same rank of thinking skills, although students from public schools was slightly higher rank of thinking skills.

2. Critical thinking skills of students who follow academic guidance model is higher than students who didn't follow it. The influence of acadamic guidance model toward the increasing of student critical thinking skills is $38 \%$. Factor of origin school of or gender partially didn't influence toward critical thinking skills of students in both groups, but origin school and gender simultaneously influence toward the ability of critical thinking of students. Male students from public schools have higher ability of critical thinking than female students from public and religious schools. Female students from religious schools have lower ability of critical thinking than female students from public schools.

3. Creative thinking ability of students who follow the academic guidance model is higher than students who didn't follow it. The influence of academic guidance model toward the increasing of creative thinking ability of students is $34 \%$. Factor of origin school or gender separately didn't influence the increasing of creative thinking ability, but origin school and gender simultaneously influence students'creative thinking ability. Male students from public and religious schools have creative thinking ability higher than female students from public and religious schools.

4. The rank of students'independent learning that followed academic guidance model is higher than students who didn't follow it. A model of academic guidance influences toward the increasing of independent learning interlay 53\%. Factor of origin school or gender separately didn't significantly influence toward the improving of students' independent learning, but origin school and gender simultaneously influence students' independent learning. Students from public schools have very high independent learning than students from religious schools, but male students'independent learning from 
religious schools is lower. For the female gender from public or religious schools have nearly same moderate rank of independent learning.

5. Independent learning in students'cognitive of who followed of a model academic guidance is higher than students who didn't follow it. The influence of academic guidance model toward independent learning in cognitives is very high, namely $83 \%$.

6. Independent learning in students'affective that followed of a model academic guidance is higher than students who didn't follow it. The influence of academic guidance model toward the increasing of independent learning in affectives is very high, namely $80 \%$.

7. Independent learning in students'conative that followed of model of academic guidance is higher than students who didn't follow it. The influence model of academic guidance toward the increasing of independent learning in conatives is very high, namely $76 \%$.

Critical thinking is a mental process of a well-organized and participate in decisionmaking process to solve problems by analyzing and interpreting data in a scientific inquiry activities. While creative thinking is the thinking process that produced the original ideas, constructive, and emphasizes the intuitive and rational aspects. Both types of thinking is called a high-level thinking (Liliasari, 1996: 115-123).

Learning for students by using the paradigm of andragogy demanding activity, independence, motivation, skills to use the power of critical thinking and creative thinking. If not supported by these aspects, then the student over time will far left and the information obtained is very limited, perhaps limited to matters that had written in a notebook that is almost functionally meaningless if the recording is without the involvement of critical thinking and creative thinking skills.

According to Beyer (1995: 12-15), a person who has the critical thinking skills have an open attitude towards different ideas, respect for honesty, respect for different opinions, respect for clarity and accuracy, look for other views that are different, and will change attitudes when there is an opinion that he considered better. Zeidler (1992: 3) states the characteristics of people who think critically: (a) have a certain mind devices that are used to approach the idea, (b) have a strong motivation to find and solve problems, (c) of skepticism is not easily accept the idea or ideas unless he can prove its truth (http://en.wikipedia.org/ wiki/creativity).

Critical thinking skills is one of the basic capital or intellectual capital is important for every person (Galbreath from http://en.wikipedia.org/wiki/critical thinking; Liliasari, 
1996: 18; Kubow from http://e-learning-bpplsp-reg5.go.id/?pilih=news) and is a fundamental part of human maturity (Penner in Liliasari, 1996: 18-19). Therefore, the development of critical thinking skills become very important for the students. Critical thinking skills using the basic thinking and analyzing the arguments brought against any interpretation of the insights to develop a cohesive pattern of reasoning and logic, the ability to understand the assumptions, formulate the problem, make deduction and induction, as well as the right decision. Every human being has the potential to grow and develop into critical thinkers who actually have the thinking patterns of relationships with existing self-management of every human being (Liliasari, 1996: 20-22).

Divergent thinking is the thinking person who is more dominated by the functioning of the right hemisphere, lateral thinking, thinking that deviate from the central issue. Divergent thinking is to think creatively to provide a variety of possible answers based on information provided with the emphasis on quantity, diversity, originality answer. Divergent thinking refers to the pattern of thinking that led to a variety of directions with a smooth marked, flexibility, and originality. Thus, divergent thinking in general are characterized by: (a) lateral, which means looking at issues from several sides, (b) diverging, spread in different directions to find the answers, (c) holistic-systemic, comprehensive, or global, (c) intuitive-imaginative, (d) independent, and (e) unpredictable.

Convergent thinking is the thinking pattern of someone who is more dominated by the left hemisphere functioning, think vertical, systematic, focused, tend to elaborate or enhance existing knowledge. Convergent thinking is the thinking that led to one direction, to give an answer or a logical inference from the information provided, with emphasis on achieving a single answer to the most appropriate. Convergent thinking associated with logical thinking, systematic, linear and predictable. Thus be stated that a convergent thinking has characteristics of: (a) vertical, it means moving in stages, (b) convergent, focused toward the single best answer, (c) systematically-structured, (d) logical, (e) rational, (f) empirical, (g) dependent, and (h) can be predicted.

From the above description can be concluded that the way of divergent and convergent thinking have bipolar characteristics. Divergent thinking which shows the flow of ideas is not linear, referring to different direction, emphasizing the overall, or holistic thinking, whereas in convergent thinking shows a linear flow of ideas, systematic, orderly, logical, and direction. 
Thus the distinction divergent thinking and convergent in fact an attempt to understand individual differences in the tendency to process information and respond to stimuli or approach a task, do tend to be divergent or convergent inclined. Categorized tend as divergent, if in facing a problem (task) tend to see it from various aspects (lateral), the process is spread with a lot of ideas, holistic, independent, and usually difficult to predict. On the other hand tend to be categorized as convergent, if in the face of a problem is always looked at from one side is focused, linear, systematic, logical, rational, dependent so much easier to predict. So each person has two ways of thinking that, just different levels of dominance. Both patterns of thinking are urgently needed in the study and so the success of learning, or even to deal with problems in life.

Just as critical thinking skills and creative thinking in learning, independent learning is important also developed in universities, especially to respond to the demands of the educational system imposed SKS. In these systems, student's independent learning is preferred. Students can not rely entirely on teachers or others in the study.

Independent learning refers to the individual needs of students to be independent and actively participate in learning in educational institutions, and in the wider community. Learning in the context of formal education mean that students gain independence as one of life skills, to help them prepare for the situations and new experiences.

Guidance to develop the independent learning to help students acquire knowledge, abilities, skills, values, and motivation that can learn to analyze situations and develop action strategies. Independent learning requires supervisors to students to take responsibility for their own learning. Individual learning responsibility comes from the belief that learning can be addressed by the business, and this belief is the critical factor that led to the persistence of individuals facing obstacles. Supervisors can help students take responsibility for learning by providing opportunities and independent learning strategies and student support initiative and participate actively in learning.

Importance of academic guidance services in university according to Walgito (1982) for several reasons:

a. How to study in university most, if not entirely, the responsibility lies on the students, so students are required to have independent learning. The main failure of students in institute is largely determined by the study habits of students who did not/not have 
independence. To avoid failure, students need guidance in order to adjust to the desired way of learning in university.

b. Age students who are experiencing the transition from adolescence to full adulthood turmoil that requires independence. In this transition period, students are often confronted with problems that can not be solved alone, so they need the guidance from a trained supervisor.

c. Almost all universities in Indonesia today using the SKS. In such systems, for example S1 program, scheduled at least eight smesters and forever 14 smesters. These provisions have an impact on the need for guidance, for students who passed 14 smester sanctioned dropouts (DO). With SKS, students were given independent to determine their study programs, under the circumstances, not least from those who have difficulty learning, so they need help to solve the problem through. The academic guidance services are required for students who experience such problems.

Thinking skills, particularly aspects of critical thinking and creative thinking in learning is an important skills to develop for students. Studying in university relies heavily on these skills, because the lectures in class with a very limited time is not likely to spill all the matters subject to the student's head, even if a broader time, students themselves are required to develop these matters creatively, because what is delivered to the student do not have to swallow it raw, but to be scrutinized to better understand and interpret the matters it receives. Lecturers are required open to students'critique, and students are required to scrutinize the matters from any source, whether the matters subject delivered lectures, the media, or electronic media as a growing right now.

Considering this model of academic guidance is quite effective to enhance critical and creative thinking skills and independent learning of students after a fairly intensive research, this model has now been implemented for new students every grade in IAIN Sheikh Nurjati Cirebon.

\section{CONCLUSION}

The ideal and real personal developments of university students as well as the system of education at university have intrigued the researcher to undergo this study. The research findings revealed that most of students show low in learning skill and independent learning, academic guidance services need serious improvement, and genuine institutional policy to maximize academic guidance services. 
Based on that background, this research is conducted to produce a model of academic guidance on the basis of the existing problems among the students low thinking skill and less independent learning in the researched site to help them develop their thinking skill and independent learning.

The study significantly shows, that the model of academic guidance is effective to enhance student's thinking skill and independent learning. It, positively, has proven the hypothesis that: First, the model of academic guidance enhenced higher level of thinking skill of experimental group students than the control group ones. Second, the model of academic guidance enhenced higher level of independent learning of experimental group than the control group ones.

\section{ACKNOWLEDGEMENTS}

Finnally, I would like to appreciation to Prof. Slamet, Ph.D and Prof. Pardjono, $\mathrm{Ph} . \mathrm{D}$, who helps me to make the article more insightful in this journal. 


\section{BIBLIOGRAPHY}

Aristo. 2008. Kemandirian Belajar. From http://www.adprima.com/dears.html, downloaded $16^{\text {th }}$ April 2008.

Beyer, BK. 1995. Improving Student Thinking, A Comprehensive Approach. Boston: Allyn \& Bacon. Inc.

Borg, WR. \& Gall, MD. 1989. Educational Research: An Introduction. $4^{\text {th }}$ Edition. New York: Longman.

Campbell, DT. \& Stanley, YC. 1966. Experimental and Quasi Experimental Design for Research. Chicago: Rand McNally College Publishing Co.

Collins, WA., in Montemayor, (ed). 1990. Advances in Adolescent Development, The Transition form Childhood to Adolescence. California: Sage.

Core Curriculum Advisory Committee. 1986. Independent Learning. From http://www. sasked. gov.sk. ca/docs/policy/cels/e17.html, downloaded $17^{\text {th }}$ April 2008.

Dahlan, M, dkk. 1996. Modul Kemahiran Berpikir Kritis dan Kreatif. Kuala Lumpur: Kementerian Pendidikan Malaysia.

deBono, E. 1998. Berpikir Lateral. Kuala Lumpur: PTS Publications and Distributors. Sdn.Bhd.

Galbreath, J. 1999. Critical Thinking. From http://en.wikipedia.org/wiki/critical thinking, downloaded $15^{\text {th }}$ April 2008.

Gormly, AV. \& Brodzinsky, DM. 1993. Lifespan Human Development. $5^{\text {th }}$ Edition, Tokyo: Harcourt Brace Collage Publishers.

Greadler, MB. 1989. Learning and Instruction, Theory to Practice. New York: McMillan Publishing Company.

Guilford, JP. 1956. Convergent and Divergent Production. From http://en.wikipedia.org/ wiki/ convergent and divergent production, downloaded $13^{\text {th }}$ April 2008.

Hurlock, EB. 1980. Developmental Psychology, A Lifespan Approach. $4^{\text {th }}$ Edition. New York: McGraw-Hill Inc.

Husen, T. 1995. Masyarakat Belajar. Jakarta: Raja Grafindo Persada.

Johnson. 2000. Convergent-Divergent. From http://faculty.washington.edu/ezent/imdt.htm, downloaded $13^{\text {th }}$ April 2008.

Konwles, MS. 1970. The Modern Practice of Adult Education, Andragogy Versus Pedagogy. New York: Association Press.

Kozma, RB; Belle, LW. \& William, GW. 1978. Instructional Techniques in Higher Education. New Jersey: Educational Technology Publications.

Kubow. 2003. Creative Thinking. From http://e-learning-bpplsp-reg5.go.id/?pilih=news, downloaded $15^{\text {th }}$ April 2008.

Lerner, RM. \& Hullsch, DE. 1983. Human Development, A Lifespan Perspectives. New York: McGraw Hill Book Company. 
Liliasari. 1996. "Beberapa Pola Berpikir dalam Pembentukan Pengetahuan Kimia oleh Siswa SMA”. Disertasi. Bandung: IKIP.

Lipps,V. \& Skoe, E., (eds). 1998. Personality Development in Adolescence, A Cros National and Lifespan Perspective. London: Routldge.

Merriam SB. \& Cafferella, RS. 1999. Learning in Adulthood. San Fransisco: Josey Bass Publishers.

Miller, PH. 1993. Theories of Developmental Psychology. $3^{\text {rd }}$ Edition. New York: W.H. Freeman and Company.

Mortensen, DG. \& Schulmuller, AM. 1976. Guidance in Today's School. New York: John Willey \& Sons Inc.

Newman, BM. \& Newman, PR. 1987. Development Through Life, A Psychosocial Approach. Chicago: The Dorsey Press.

Nickerson, R; Perkins, D. \& Smith, E. 1985. The Teaching of Thinking. New Jersey: Lawrence Erlbaum.

Nor, S. \& Dahlan, M. 2000a. Kemahiran Berpikir dalam Pengajaran dan Pembelajaran Sain. Kuala Lumpur: Kementrian Pendidikan Malaysia.

Nor, S. \& Dahlan, M. 2000b. Kemahiran Berpikir Kritis dan Kreatif. Kuala Lumpur: Longman.

Novak, JO. \& Gowin, DB. 1999. Learning How to Learn. London: Cambridge University Press.

Preisseisen, BZ., in Costa, AL., (ed). 1985. Developing Minds, A Resource Book for Teaching Thinking. Alexandria: ASCD.

Rampingan, MJ; Habiburrahman, RL. \& Tobing. 1981. Model Mengajar dalam Pendidikan IPA. Jakarta: P3G Depdikbud.

Semiawan, C. 1992. Dasar Pendidikan dan Makna Belajar. From http//:mijischool multiply. com/journal/item/36, downloaded $12^{\text {th }}$ April 2008.

Sidjabat, BS. 2008. Prinsip Pedagogi dan Andragogi. From http://www.tiranus.net/?p20, downloaded $3^{\text {rd }}$ March 2008.

Steinberg, LD. 1993. Adolescence. $3^{\text {rd }}$ Edition. New York: McGraw-Hill.

Trilling \& Hood. 1999. Hakikat Kreativitas. From http://artikel pendidikan.blogspot.com/ 2008/01/ hakikat kreativitas.html, downloaded $15^{\text {th }}$ April 2008.

Wahidin. 2004. "Peta Konsep, Peta Vee, dan Kemahiran Berpikir dalam Pengajaran Kimia". Disertasi. Malaysia: Universitas Kebangsaan.

Walgito, B. 1982. Bimbingan dan Konseling di Perguruan Tinggi. Yogyakarta: Fak Psikologi UGM.

Wedmeyer. 1973. Independent Learning. From http://www.heghlaid schoolcvirtualib.org.uk/ itt/whole learner independent.htm, downloaded $16^{\text {th }}$ April 2008.

Zeidler, et al. 1992. Creativity. From http://en.wikipedia.org/wiki/creativity, downloaded $15^{\text {th }}$ April 2008. 